\title{
SOCIODEMOGRAPHIC FACTOR RELATIONSHIP WITH INFANT SURVIVAL IN INDONESIA
}

\author{
Yasmine Nurfirdaus $^{1}$, Philip Etabee Macdonald Bassey ${ }^{2}$ \\ ${ }^{1}$ Faculty of Public Health, Universitas Airlangga, 60115 Surabaya, East Java, Indonesia \\ ${ }^{2}$ Department of Public Health, University of Calabar, Cross River State, Nigeria \\ Corresponding Author: Yasmine Nurfirdaus \\ E-mail: yasmine.nurfirdaus-2016@fkm.unair.ac.id
}

\begin{abstract}
Child survival can be reflected in the presence of the Infant Mortality Rate (IMR). Indonesia has an Infant Mortality Rate (IMR) according to the 2017 IDHS, which reaches 24 deaths per 1000 live births. This figure has decreased compared to a survey conducted by the 2012 IDHS, where infant mortality reached 32 deaths per 1000 live births. Even though it experienced a decrease, the IMR in Indonesia was higher when compared to the IMR in other Southeast Asian countries. Socioeconomic factors for individuals, families, and communities, including the influence of infant mortality. Not only that, but infant mortality can also be due to the absence of awareness of maternal health. Thus, this study aims to determine several variables related to survival in infants in Indonesia. This type of research is a non-reactive study. This study uses quantitative analysis and a methodical approach with a cross-sectional approach that takes data from the 2017 IDHS. This study took a sample following the 2017 IDHS with the criteria that mothers who had babies still drank breast milk, were born single, and were still alive after the first three days in Indonesia. The number of respondents in this study was 7,599 mothers with babies. Analysis of the research data using Chi-Square analysis. Bivariable analysis shows that infants' survival has a relationship with the mother's education, type of area, and welfare level. However, infant survival also has no association with the age of the mother and birth attendants. Counseling pregnant women regarding risks, causes,
\end{abstract}

Keywords: infant survival, infant death

\begin{abstract}
ABSTRAK
Kelangsungan hidup pada anak dapat dicerminkan dengan adanya Angka Kematian Bayi (AKB). Indonesia memiliki Angka Kematian Bayi (AKB) menurut SDKI 2017 kematian pada bayi mencapai angka 24 kematian setiap 1000 kelahiran hidup, angka tersebut mengalami penyusutan dibandingkan survei yang dilakukan SDKI 2012 dengan kematian bayi mencapai angka 32 kematian setiap 1000 kelahiran hidup. Meski mengalami penyusutan namun AKB di Indonesia lebih tinggi apabila dibandingkan AKB di negara Asia Tenggara yang lain. Faktor ekonomi sosial baik pada individu, keluarga, serta masyarakat termasuk pengaruh dari adanya Kematian Bayi. Tidak hanya itu kematian bayi juga dapat dikarenakan tidak adanya kesadaran kesehatan ibu. Sehingga, penelitian ini memiliki tujuan untuk mengetahui beberapa variabel yang berhubungan dengan kelangsungan hidup pada bayi di Indonesia. Jenis penelitian yang dilakukan termasuk penelitian non reactive study. Penelitian ini menggunakan penelitian kuantitatif dan pendekatan metode dengan potong lintang yang mengambil data dari SDKI 2017. Penelitian ini mengambil sampel mengikuti SDKI 2017 dengan kriteria ibu yang memiliki bayi masih meminum ASI, lahir tunggal dan masih hidup setelah 3 hari pertama di Indonesia. Jumlah responden penelitian ini adalah 7.599 ibu yang terdapat bayi. Analisis data penelitian ini menggunakan analisis Chi-Square. Analisis bivariabel diketahui bahwa kelangsungan hidup pada bayi memiliki hubungan dengan pendidikan ibu, tipe wilayah, dan tingkat kesejahteraan. Namun kelangsungan hidup bayi juga tidak memiliki hubungan dengan umur ibu dan penolong persalinan. Penyuluhan kepada ibu hamil mengenai risiko, penyebab, dan upaya pencegahan kematian bayi dan dilakukan pemantauan mengenai pemberian ASI serta konseling pemeriksaan pada saat kehamilan.
\end{abstract}

Kata Kunci : Kelangsungan Hidup Bayi, Kematian Bayi, Bayi 


\section{INTRODUCTION}

Children are the nation's hope for a bright future. The survival of children is essential, especially for some countries. These children's survival can be reflected in the Infant Mortality Rate (IMR) existence, which is still classified as high (Hajarisman, Karyana, and Rosiana, 2016). IMR can be a benchmark that can be used to see a country and the economic condition of the population as a whole, which can be seen from the child's health status (Tarigan et al., 2017).

Infant mortality is the event of the death of a baby who has been born at the age of 0-12 months. Southeast Asia has the third-highest number of infant deaths in 2015, with 22 deaths per 1000 live births. Indonesia and Cambodia are above the IMR in Southeast Asia, with 23 deaths per 1000 live births and 25 deaths per 1000 live births, while the Philippines is the same as IMR in Southeast Asia, which is 22 deaths per 1000 live births (Fitri, Adisasmita and Mahkota, 2017).

According to the IDHS in 2012, the IMR, according to the survey, was 32 deaths per 1000 live births. When compared with the study conducted by the IDHS in 2017, it can be seen that there was a decrease from the survey in the previous period to 24 deaths per 1000 live births. Although there has been a decrease in IMR in Indonesia, the IMR in Indonesia can be high when viewed from the IMR in other Southeast Asian countries. According to a World Health Organization (WHO) report, in 2015 globally, there were 4.5 million babies who died in their first year of life (Widayanti and Wijayanti, 2018).

According to the Ecological Theory that Penny Price has put forward in the book Chapter Maternal and Child Health Care Strategic, there are three parts of the factors that cause death and morbidity in mothers and children, namely: (1) direct, which can be during pregnancy, childbirth, and children, toddlers, adolescents, adults, and babies. (2) intermediate, which may include the availability of health facilities, quality of service, easy access to health facilities, service acceptance, and logistics. (3) the underlying can have socioeconomic, traditional habits, poverty, politics, gender discrimination, environment, residence, culture, maternal syndrome, and others (Elisanti, Purnomo, and Melaniani, 2013).

Socioeconomic factors for both individuals, families, and communities, including the influence of infant mortality, not only socioeconomic factors but also maternal education is also a factor that has a strong effect on infant mortality (Aisyan, Jannah and Wardani, 2013).

Sufficient knowledge of parents will help identify diseases in children correctly and immediately provide first aid and appropriate early treatment. Wrong handling can make the disease in children get worse. According to research conducted on five babies, it was found that one baby died due to congenital heart defects. At the time of the survey, two babies were suffering from diarrhea, and one baby being treated at the hospital. Another baby was only being treated at home due to limited costs, one the other baby had ARI, and only one baby was said to be healthy when the survey was conducted (Napitupulu, Yusad, and Jalil, 2012).

Deaths that occur in infants can be caused by the absence of health awareness in the mother. Not only health awareness in infant mortality, but there are also many influencing factors, such as mothers who do not check their womb on time to health services. Other influencing factors were mothers who are pregnant at a young or old age, the distance between having children is too close, the lack of nutritious intake for the mother and the baby, the environment is not good. Besides all that, pregnant women with unhealthy conditions will cause the mother's womb to be disturbed. The disturbance can occur in the mother's psychological, environmental, social, and cultural factors (Abdiana, 2017).

Currently, the government is making efforts to reduce infant and child mortality in Indonesia, which has decreased in the last ten years. Although there has been a decrease in Indonesia's infant mortality, it can be considered quite a lot when seen with IMR in other Southeast Asian countries. This situation can occur due to health care at birth. Congenital diseases and poor living conditions can also cause infant mortality. Infant mortality rates can indicate gaps in the 
delivery of severe health services (UNICEF, 2019).

This study aimed to determine several variables that have a relationship with survival in infants in Indonesia. In particular, to determine the relationship between age factors in mothers, the mother's highest education, type of area, level of welfare, and assistance during childbirth with infant survival.

\section{METHODS}

This research is a non-reactive study, which means that this type of research uses secondary data. This study uses quantitative analysis, and the approach uses a crosssectional approach based on secondary data from the IDHS in 2017 with exposures that occurred before the research was done. The goal is to determine the relationship between several variables and survival in infants. Data were obtained in a survey of analytical studies on the 2017 Indonesian Demographic Health Survey results.

In this study, there is a dependent variable, namely survival in infants, and independent variables, namely the mother's age, mother's education, type of area, level of welfare, and assistance at delivery. Selection of respondents begins with selecting according to their exposure. Respondents who have criteria are mothers who have babies who still drink breast milk, were born single, and are still alive after the first three days in Indonesia.

The data analysis used was descriptive analysis and Chi-Square analysis. Descriptive analysis is used to explain the table of the dependent variable and the independent variable. The Chi-Square analysis was used to determine the relationship between infant survival and each independent variable in the study. The chi-square analysis results have a value of $\mathrm{P}<0.05=\alpha$ so that this variable is known to have a relationship with infant survival.

\section{RESULT}

Based on Table 1, it can be shown that the age variable $<20$ years is $2.8 \%$ and $\geq 35$ years is $30.9 \%$, so this can indicate that the age of the respondent is at the age at risk. Most of the most increased education taken by respondents is primary education, with a total percentage of $26.8 \%$ for mothers' highest education. If the mother's education level is high, providing health services and providing some health information will not be a problem. Among the types of urban and rural areas, most respondents live in rural areas with a percentage of $51.3 \%$. According to the respondents' welfare level, it can indicate that the respondents with a low level of welfare are still classified as significant with a percentage of $49.2 \%$.

Table 1. Characteristics of Respondents according to Mother's Age, Mother's Education, Type of Area, Level of Welfare and Assistance at Delivery.

\begin{tabular}{lcc}
\hline Characteristics & f & \% \\
\hline Mother's age (in years) & & \\
\hline$<20$ & 211 & 2.8 \\
$20-34$ & 5043 & 66.4 \\
$\geq 35$ years & 2345 & 30.9 \\
\hline Mother's Education & & \\
\hline Never at school & 134 & 1.8 \\
Primary education & 2035 & 26.8 \\
Middle education & 4181 & 55 \\
Higher education & 1249 & 16.4 \\
\hline Region Type & & \\
\hline Urban & 3699 & 48.7 \\
Rural & 3900 & 51.3 \\
\hline Prosperity level & & \\
\hline Low & 3735 & 49.2 \\
Moderate & 1330 & 17.5 \\
Able & 2534 & 33.3 \\
\hline Birth attendant & \\
\hline Health workers & & \\
Non-Health workers & 271 & 3.6 \\
\hline
\end{tabular}

Based on Table 2, the mother's age has a category of age $<20,20-34$, and $\geq 35$ getting a $\mathrm{P}$-value $=0.057$, so it can be analyzed that $\mathrm{H} 0$ is accepted, which means that survival in infants has no relationship with the mother's age.

In the variable of maternal education, getting a $\mathrm{P}=0.000$, it can be analyzed that $\mathrm{HO}$ is rejected, which means that the baby's survival has a relationship with the mother's education.

The area type variable has urban and rural categories, getting a $\mathrm{P}$-value $=0.002$. It can be analyzed that $\mathrm{H} 0$ is rejected, meaning that it has a relationship between the respondent's area type and infant survival. 
Table 2. Results of the Analysis of the Relationship of Infant Survival according to Mother's Age, Mother's Education, Type of Area, Level of Welfare, and Assistance at Delivery.

\begin{tabular}{llccccc}
\hline \multirow{2}{*}{ Variable } & & \multicolumn{3}{c}{ Baby Survival } & $\begin{array}{c}\text { Chi- } \\
\text { Square }\end{array}$ & $\begin{array}{c}\text { P- } \\
\text { value }\end{array}$ \\
\cline { 3 - 5 } Mother's Age & Die & Life & Total & & \\
(in years) & $20-34$ & 1 & 210 & 211 & & 0.057 \\
& $\geq 35$ & 48 & 4995 & 5043 & 5,740 & \\
& Total & 36 & 2309 & 2345 & & \\
\hline Mother's Education & No school & 85 & 7514 & 7599 & & \\
& Basic education & 36 & 128 & 134 & & \\
& Middle education & 29 & 4152 & 4181 & 28,281 & 0,000 \\
& higher education & 14 & 1235 & 1249 & & \\
& Total & 85 & 7514 & 7599 & & \\
\hline Region Type & Urban & 27 & 3672 & 3699 & & \\
& Rural & 58 & 3842 & 3900 & 9,170 & 0.002 \\
& Total & 85 & 7514 & 7599 & & \\
\hline Prosperity level & Low & 56 & 3679 & 3735 & & \\
& Moderate & 7 & 1323 & 1330 & \multirow{2}{*}{0.00550} & \\
& Able & 22 & 2512 & 2534 & & \\
& Total & 85 & 7514 & 7599 & & \\
\hline Birth attendant & Health workers & 79 & 7249 & 7328 & & \\
& Non-Health workers & 6 & 265 & 271 & 2,108 & 0.146 \\
& Total & 85 & 7514 & 7599 & & \\
\hline
\end{tabular}

There are three categories of respondents' welfare variables, namely low, moderate, and capable. According to the research results getting a $\mathrm{P}$-value $=0.005$, it can be analyzed that $\mathrm{HO}$ is rejected and has a meaningful relationship between the dependent variable and the independent variable. This result means that the level of the respondent's welfare is related to survival in infants.

In the respondent's birth attendant variable, according to the results of the study, the value of $\mathrm{P}=0.146$ so that from these results it can be analyzed tha $\mathrm{t} \mathrm{HO}$ is accepted, which means that the birth attendant has no relationship between the respondent's place of delivery and the survival of the baby.

\section{DISCUSSION}

\section{Relationship Between Mother's Age and Infant Survival}

Based on the Chi-Square test, maternal age has no relationship with infant survival. Although there is no relationship between the baby's survival and the mother's age, the mother's age must still be considered.
According to Mahampang, Cahyati, and Wahyuningsih (2011), women aged $<19$ years and $>35$ years have high-risk pregnancies based on obstetric application. Women who deliver at the age $<20$ years and $>35$ years will be prone to bleeding after delivery and can cause perinatal death (Mahampang, Cahyati, and Wahyuningsih, 2011).

The results of the study are not the same as the theory in the Indonesian Children's Profile book 2019 that babies are at risk of death if the mother's age is <20 years, and can have a 2-fold chance of dying before the baby reaches one year old compared to babies from the mother's age. $\geq 20$ years. Mortality in infants with mothers aged $<18$ years and Age $\geq 35$ years is the highest rate (Ministry of Women's Empowerment and Child Protection, 2019).

Another research conducted by Dewi (2015) known there is still the mother's age in the risk group. The risk of perinatal death at age $<20$ years and $>35$ years is not only based on obstetric application, socially at that age is one of the markers that pregnancy is not planned to occur without attention to examinations during pregnancy so that the risk of death in infants (Dewi, 2015). 


\section{Relationship Between Maternal Education and Survival in Infants}

Based on the Chi-Square test, maternal education has a relationship with infant survival. Several studies that are in line state that there is a correlation between infant mortality and maternal education. If the mother's education is high, then the infant mortality will below, so the opposite is if the mother's education is low, then the infant mortality will be high(Ensor et al., 2010). One study also explained that mothers with low education have a 1.5 times higher mortality rate for children aged 6-35 months than mothers with higher education (Dewi, 2015).

The results of the research are also following those carried out in Ghana. According to Kanmiki et al. (2014), mothers who have tertiary education will receive antenatal care and easy access. Maternal education can also contribute by understanding the benefits that affect the survival of both mother and child.

\section{Relationship Between Territorial Type and Infant Survival}

Based on the Chi-Square test, the type of residence area has a relationship with infant survival. According to several similar studies, it is stated that the place where the respondent lives are very influential on the survival of the baby. According to Shiferaw, Zinabu, and Abera (2012), on research conducted in Ethiopia, housing both urban and rural is essential to determine access to services and exposure to information related to reproductive health and other aspects of life.

The results of the research are also following what was done by Dewi (2015). According to Dewi, the baby's health will have a harmful impact due to the customs that are still adhered to by the village community. Infant mortality will be higher if community habits do not support health behavior. This statement also follows Mosley's (1984) theory in Laksana and Syafiq (2014)that children and babies who live in urban areas will have a lower risk of child and infant mortality than children and babies who live in rural areas. This condition is because there are differences between parents who live in rural areas and parents who live in urban areas (Laksana and Syafiq, 2014).

\section{The Relationship Between the Level of Well- Being and the Survival of the Baby}

Based on the Chi-Square test, the respondents' welfare level has a relationship with infant survival. Several studies have stated that children who have parents with less socioeconomic risk of dying 3.75 times than children with socio-economically well-off children. Poverty and malnutrition are often associated with low economic status because they can make children less likely to live (Dewi, Agus Wilopo, and Wibowo, 2017).

Socioeconomic differences play a role in healthcare-seeking behavior, for those whose family welfare level can be more likely to use health care facilities than those whose family welfare level is less (Kanmiki et al., 2014).

\section{The Relationship Between Helper at Delivery of Respondents and The Survival of the Baby}

Based on the Chi-Square test, the respondent's helper at delivery had no relationship with the baby's survival. These results are not in line with the theory, which states that problems will arise if the birth attendant is not a health worker, causing a high rate of morbidity and mortality for mothers and babies. This situation because birth attendants must have exceptional obstetrics skills that can only be done by professional health workers (Mahampang, Cahyati, and Wahyuningsih, 2011).

This research is also not following the ecological theory put forward by Penny Price in the book Chapter Maternal and Child Health Care Strategically, which states that health services and health facilities influence morbidity and mortality of mothers and babies. In general, if non-health workers carry out delivery assistance, it will cause pain in the mother and generate a high infant mortality rate (Elisanti, Purnomo, and Melaniani, 2013).

Other studies have also suggested that the factors that determine early breastfeeding success and reduce pre-lactation feeding are the suitable birth attendants. Although non-health workers have received training, their skills are insufficient, especially regarding obstetrics (Dewi, Agus Wilopo, and Wibowo, 2017). 


\section{CONCLUSIONS AND SUGGESTIONS}

\section{Conclusions}

The baby's survival has a relationship with the mother's education level, the area where the respondent lives, and the level of welfare the respondent has. The baby's survival has no relationship with the age of the mother and the helper at delivery.

\section{Suggestion}

Based on the conclusion, the researchers suggest improving infant survival, educating the public about the risks, causes of infant mortality, and efforts to prevent infant mortality. It can also be done that monitoring regarding breastfeeding and counseling during pregnancy, especially for mothers with low levels of welfare and the need for other research that is more specific on this topic, can also add several variables related to this case.

\section{REFERENCES}

Abdiana, A., 2017. Determinants of Infant Mortality in Payakumbuh City. Andalas Public Health Journal, 9 (2), pp. 88.

Aisyan, SDS, Jannah, SN and Wardani, Y., 2013. The Relationship Between Family Socio-Economic Status and Perinatal Mortality in the Work Area of Puskesmas Baamang Unit II Sampit Central Kalimantan January-April 2010. Journal of Public Health, 5 (1), pp. 35-44.

Dewi, U., 2015. Sociodemographic Factors with Infant Survival in Indonesia (2007 IDHS Data Analysis). Manuntung Scientific Journal, 1 (2), pp. $172-180$.

Dewi, U., Agus Wilopo, S. and Wibowo, T., 2017. Provision of Pralactation Feeding with the Survival of Babies in Indonesia (2007 IDHS Data Analysis). Journal of Reproductive Health, 1 (4), pp. 56-73.

Elisanti, AD, Purnomo, W. and Melaniani, S., 2013. Implementation of Partial Least Square for Toddler Health Status in Indonesia. Journal of Biostatistics and Population, 2 (2), pp.99-107.

Ensor, T., Cooper, S., Davidson, L., Fitzmaurice, A. and Graham, WJ, 2010. The impact of economic recession on maternal and infant mortality: Lessons from history. BMC Public Health, [online] 10 (1), pp. 727. Available at: $<$ http://www.biomedcentral.com/14712458/10/727>.

Fitri, A., Adisasmita, A. and Mahkota, R., 2017. The effect of birth spacing on infant mortality in Indonesia, the Philippines, and Cambodia (Health Demographic Survey Data Analysis). Indonesian Journal of Health Epidemiology, 1 (2), pp. 45-52.

Hajarisman, N., Karyana, Y. and Rosiana, D., 2016. The Influence of Health Facilities and Socio-Economic Factors on the Degree of Child Survival through Structural Equation Modeling. ETHOS (Journal of Research and Service), 2008, pp. 233.

Kanmiki, EW, Bawah, AA, Agorinya, I., Achana, FS, Awoonor-Williams, JK, Oduro, AR, Phillips, JF, and Akazili, J., 2014. Socioeconomic and demographic determinants of underfive mortality in rural northern Ghana. BMC International Health and Human Rights, 14 (1), pp. 1-10.

Ministry of Women's Empowerment and Child Protection, 2019. Profile of Indonesian Children in 2019.

Laksana, MP and Syafiq, A., 2014. Determinants of Infant Mortality Rate in Indonesia (Secondary Data Analysis of Indonesian Demographic Health Survey 2012). University of Indonesia.

Mahampang, U., Cahyati, WH and Wahyuningsih, AS, 2011. Mother and Infant Factors Associated with Perinatal Mortality. KESMAS Journal of Public Health, 7 (1), pp. 4150.

Napitupulu, A., Yusad, Y. and Jalil, A., 2012. Factors related to the survival of babies being treated at the District General Hospital Labuhan Batu Utara Regency in 2012.

Shiferaw, YA, Zinabu, M. and Abera, T., 2012. Determinant of Infant and Child Mortality in Ethiopia. SSRN Electronic Journal.

Tarigan, IU, Afifah, T., Simbolon, D., Daya, PS, Health, P., Litbangkes, B., Health, K., Effort, P., Society, K. and Health Bengkulu, P., 2017 Factors Associated with Infant Care in Indonesia: A 
Multilevel Analysis Approach. Journal of Reproductive Health, 8 (1), pp. 103118.

UNICEF, 2019. Health: Providing the Best Chance of Survival for Children. [online] UNICEF Indonesia. Available at: <https://www.unicef.org/indonesia/id k Health> [Accessed 28 Apr 2020].

Widayanti, DA and Wijayanti, AC, 2018. Factors Associated with Infant Mortality in Boyolali Regency. pp. 689-698. 